\title{
On the problem of preserving the biodiversity of the plant world in the Pripyat Polesie
}

\author{
Aliaksandr Mialik ${ }^{1 *}$ \\ ${ }^{1}$ Central Botanical Garden of the National Academy of Sciences of Belarus, Minsk, Belarus
}

\begin{abstract}
The article deals with the problems of preserving the diversity of the plant world in the Pripyat Polesie (a natural region of the southern part of Belarus). It is shown that when compiling lists of vulnerable species, not only plants from the Red book of the Republic of Belarus should be taken into account, but also species that are protected at the international level, as well as those that grow on the borders of their area. Currently, there are 88 species that have a category of national conservation significance, and 80 taxa are included in the list of species of wild plants and fungi that need preventive protection in the Red book of the Republic of Belarus. A total of 225 species in the native flora are located on the borders of the areas, of which only 111 are officially protected. The international protected status has 61 species, which increases the sozological value of the studied flora. The category of probably extinct includes 29 species, the probability of their re-discovery cannot be completely excluded. The presented data, together with the General features of the flora and vegetation of the Belarusian Polesie, justify the feasibility of compiling a regional Red book.
\end{abstract}

Biodiversity conservation has been one of the most important global environmental issues for many decades due to the increasing anthropogenic pressure on natural ecosystems. Currently, an increasing number of plant and animal species are vulnerable, which requires special measures for their protection and conservation in the wild. In Belarus, this problem is solved by compiling and updating the national Red book every 10 years, which publishes lists of rare and endangered plant species. According to the legislation of the Republic of Belarus, only those species for which there is data on monitoring of the plant world, the state cadastre and scientific research can be classified as such. In total, the Red book of the Republic of Belarus includes 189 species of vascular plants, each of which is assigned a category of national ecological significance. Another 115 species are included in the list of wild plants and fungi that need preventive protection [1].

However, when implementing practical measures for the protection of rare and vulnerable plant species, problems often arise due to both the completeness of the study of the flora and the peculiarities of geographical distribution and frequency of occurrence of individual plant species within different natural areas of Belarus.

One of the natural areas of the southern part of Belarus, which is characterized by pronounced features of vegetation and flora, is the Polesie lowland. Taking into account the

\footnotetext{
*Corresponding author: aleksandr-myalik@yandex.by
} 
large-scale anthropogenic impacts on the ecosystems of this territory, the problems of preserving the biodiversity of the plant world are particularly relevant here. The purpose of this work is to assess the problems of preserving the diversity of vascular plants in the Pripyat Polesie - a natural region that occupies the Central part of the Belarusian Polesie and most fully characterizes its floristic features.

The territory of the Pripyat Polesie is a separate natural district located in the Central part of the Polesie lowland in the South of Belarus (fig. 1.). This territory is a system of alluvial plains with sections of water-glacial and moraine plains [2]. At present, the region still stands out for its higher wetlands and woodlands compared to nearby ones. However, the consequences of large-scale drainage of swamps carried out here in the second half of the XX century, had a significant impact on the state of modern vegetation and flora.

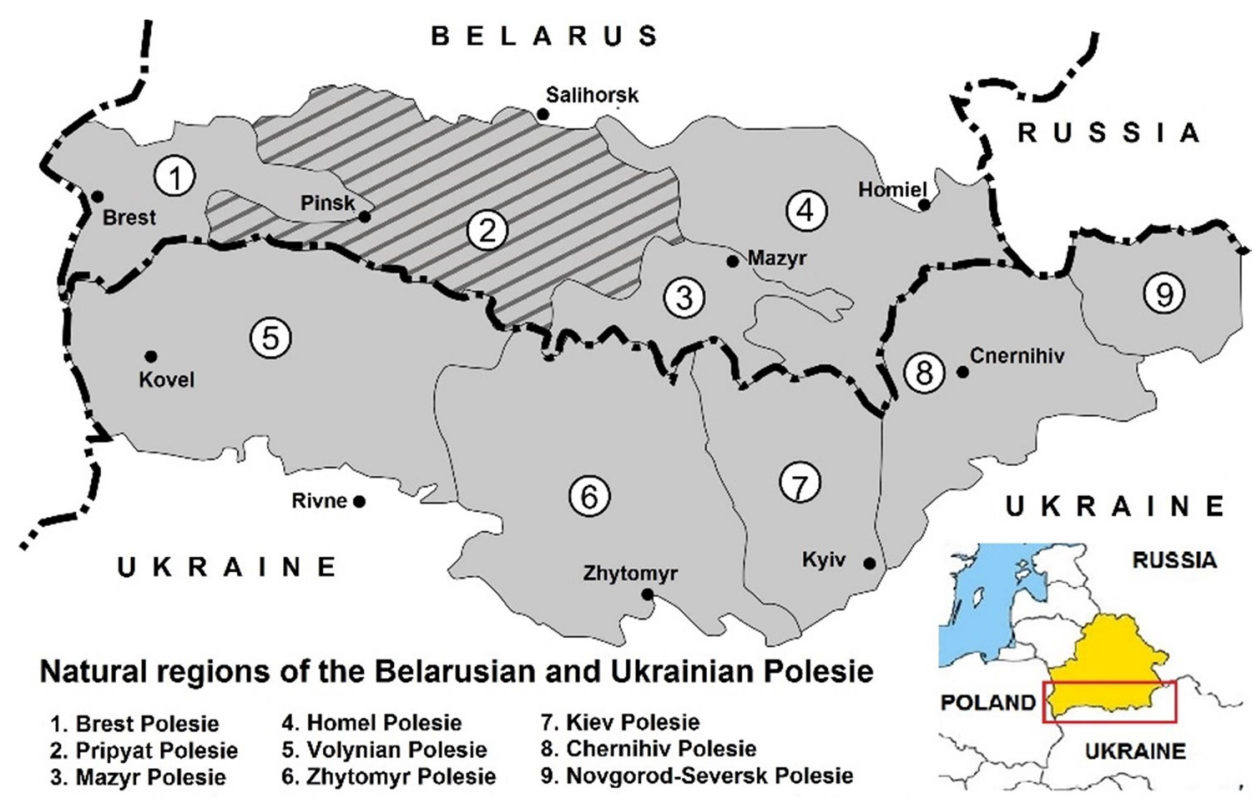

Fig. 1. Position of the Pripyat Polesie within the Polesie lowland.

The modern native flora of Pripyat Polesie is represented by 881 species of vascular plants, which belong to 370 genera and 117 families. Its taxonomic composition is typical for the temperate latitudes of the Holarctic and the ratio of the leading families corresponds to the Cyperaceae-type and Scrophulariaceae-subtype. The boreal-temperamental character of the flora is indicated by the high positions of the genera Carex, Potamogeton, Salix, Viola and Juncus. The Mediterranean influence is shown in the presence of the spectrum of genera Veronica and Trifolium in the head. About $25 \%$ of native species are located on the borders of the range, which allows us to consider the Pripyat Polesie as a component of the Polesie horological disjunction and the transcontinental boreal ecotone. The latter represents a transition zone between the boreal (taiga-forest) and subboreal (forest-steppe and steppe) vegetation belts. This circumstance indicates a high vulnerability of the native flora due to the significant number of plant species growing on the borders of the areas [3].

In accordance with this, local floristic features require the use of several different approaches when selecting a rare component of the flora. To address issues of effective conservation of flora diversity, it is necessary to take into account not only plant species included in the Red book of the Republic of Belarus, but also taxa that are protected at the international level, rare plants due to their horology, as well as species that are considered probably extinct in the region. When identifying groups of vulnerable species and 
compiling their lists, we used the results of our own floristic research carried out in the region in 2010-2019, materials from herbarium collections (LE, MSK, MSKH, MSKU, MW).

In total, 168 species of vascular plants have been identified as part of the flora of Pripyat Polesie, which have a sozological value according to official environmental documents. Of these, 88 species have a protected category of the Red book of the Republic of Belarus, and 80 are included in the list of species of wild plants and fungi in need of preventive protection.

According to the criteria of the International Union for conservation of nature, 11 species of flora are classified as CR - endangered. Among them are Equisetum telmateia Ehrh., Daphne cneorum L., Hydrocotyle vulgaris L. and a number of other plants corresponding to the I category of the red book of the Republic of Belarus. Endangered (EN) are 16 species (Caulinia minor (All.) Coss. et Germ., Hedera helix L., Urtica kioviensis Rogow. and others), which correspond to the II category of national significance. The vulnerable group (VU) includes 35 representatives of flora (Allium ursinum L., Drosera intermedia Hayne, Veratrum lobelianum Bernh. and others), the protected status of which corresponds to category III. A total of 26 species from category IV (Genista germanica L., Iris sibirica L., Listera ovata (L.) R. Br., etc.) are currently potentially vulnerable - category NT. The list of plant species in need of preventive protection includes 80 taxa. Among them, 55 species (Botrychium lunaria (L.) Sw., Lythrum hyssopifolia L., etc.) correspond to the category (LC) requiring attention. Insufficiently studied (DD) are 25 species (Betula obscura Kotula, Juncus capitatus Weigel, etc.) [1].

A total of 61 representatives of the native flora of the Pripyat Polesie have an international conservation status. The species protected in Ukraine include 55 taxa (Betula humilis Schrank, Succisella inflexa (Kluk) Beck , Utricularia intermedia Hayne, etc.) [4], which emphasizes the important role of the Pripyat Polesie in preserving the biodiversity of the entire transborder Polesie region. In accordance with Annex II to the Convention on international trade in endangered species of wild fauna and flora, CITES protects 20 representatives of the family Orchidaceae (Dactylorhiza baltica (Klinge) Nevski, Epipactis palustris (L.) Crantz, Hammarbya paludosa Kuntze, etc.). 11 taxa are protected under Annex I to the Berne Convention for the protection of wild fauna and flora and natural habitats in Europe: Jurinea cyanoides Rchb., Salvinia natans (L.) all. and others. Only 6 species (Aldrovanda vesiculosa L., Thesium ebracteatum Hayne, etc.) are protected under the European Union Directive on the protection of natural habitats of wild flora and fauna [1].

In accordance with the above, it can be noted that the territory of the Pripyat Polesie is distinguished by a high sozological representativeness and has a significant value in preserving the diversity of the flora of the entire Belarusian Polesie and Belarus (fig. 2.). Currently, the gene pool of $46.5 \%$ (88 out of 189) of nationally protected vascular plant species is preserved here. At the same time, the area of Pripyat Polesie is no more than 30 $\%$ of the area of the entire Belarusian Polesie and only $10 \%$ of the area of Belarus. 


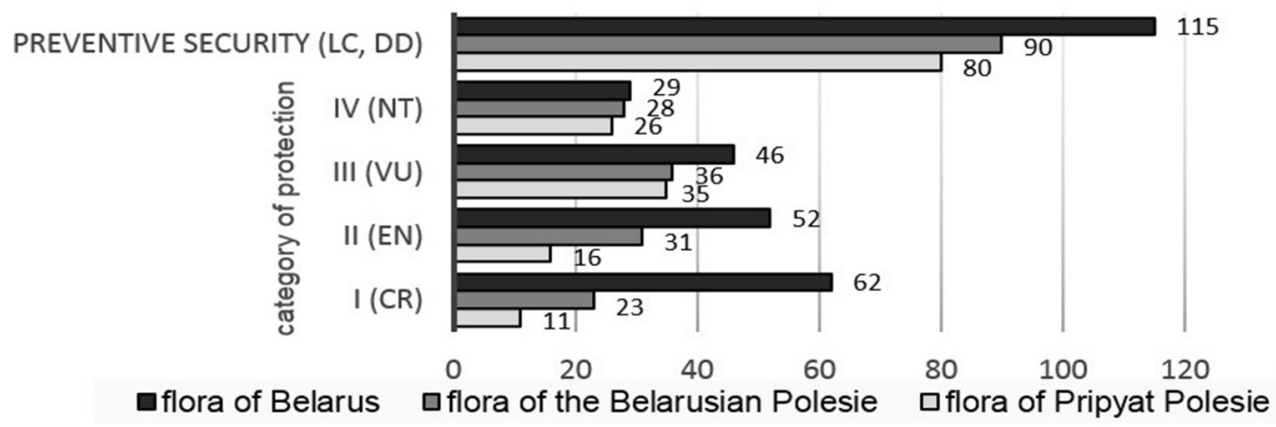

Fig. 2. Sozological representativeness of the Pripyat Polesie flora.

Despite the fact that the compact territory of the Republic of Belarus has a small area (207.6 square kilometres), it is located within 3 geobotanical subzones (broad-leaved pine forests, hornbeam-oak-dark coniferous forests and oak-dark coniferous forests), each of which has specific features of flora and vegetation cover. This explains not only the different florgenetic status of some protected species within different natural regions of the Republic, but also the degree of rarity of some species due to the peculiarities of their distribution.

A total of 225 species $(25.54 \%)$ are located in the Pripyat Polesie at the limit of their natural distribution (on the border of the range, near it, in island localities, or form a regional and local disjunction). Such representatives of the flora are particularly vulnerable to natural factors and anthropogenic impact because they grow in stressful environmental conditions. Table 1 shows the groups of areals of these species.

Table 1. Distribution of horologically determined species of Pripyat Polesie flora by areal groups.

\begin{tabular}{|c|c|c|c|c|}
\hline \multirow{2}{*}{ Areal group } & \multirow{2}{*}{$\begin{array}{c}\text { Number of } \\
\text { species }\end{array}$} & $\begin{array}{c}\text { species in } \\
\text { island } \\
\text { habitats }\end{array}$ & $\begin{array}{c}\text { plants that form } \\
\text { a regional } \\
\text { disjunction }\end{array}$ & $\begin{array}{c}\text { plants that form } \\
\text { a local } \\
\text { disjunction }\end{array}$ \\
\hline North & 75 & 8 & - & 1 \\
\hline South & 79 & 17 & 21 & 5 \\
\hline East & 42 & 6 & 4 & 1 \\
\hline Western & 21 & 1 & - & 1 \\
\hline $\begin{array}{c}\text { Local } \\
\text { disjunction }\end{array}$ & 8 & - & - & 8 \\
\hline Total & 225 & 32 & 25 & 16 \\
\hline
\end{tabular}

The most numerous is the southern areal group, which unites species located at the southern limit of natural distribution. Most of them belong to moderately cold-resistant arcto-boreal and boreal plants (Carex brunnescens (Pers.) Poir., Eriophorum gracile W. D. J. Koch ex Roth, Goodyera repens (L.) R. Br., etc.) There are 17 species from this group in island areas: Hammarbya paludosa Kuntze, Ranunculus reptans L. and others. These species are particularly vulnerable in the natural conditions of the South of Belarus.

The Northern areal group combines 75 species with the Northern borders of their ranges. It is represented by heat-loving plants (Lythrum hyssopifolia L., Trifolium fragiferum L., Scabiosa ochroleuca L., etc.), whose distribution within Belarus is limited to the territory of Polesie. Only 8 representatives from this group (Equisetum telmateia Ehrh., Rhododendron luteum Sweet, etc.) are located in island areas of growth. Some heat-loving species (Stachys recta L., Chondrilla juncea L., etc.) are characterized by progressive 
expansion of their range to the North. In the Central part of Belarus, these species can be considered adventitious.

At the Eastern limit of natural distribution there are 42 species, among which there are more numerous plants distributed in Central and Atlantic Europe (Carex davalliana Sm., Hedera helix L., Hypericum humifusum L., Teesdalia nudicaulis (L.) W. T. Aiton, etc.). The Frequency of occurrence of species in this group is decreasing in the Eastern direction due to the increasing continentality of the local climate.

The Western areal group is the smallest and is represented by 21 species of EuropeanSiberian and Eastern European distribution (Asparagus officinalis L., Agrostis diluta Kurczenko, Koeleria delavignei Czern. ex Domin, etc.). Within Belarus, the distribution of most of these plants is limited to the valleys of the Dnieper and Pripyat rivers.

Plants with a disjunctive type of habitat are of particular interest among the chorologically determined flora species of the Pripyat Polesie. A total of 25 such species have been identified, most of which grow at the southern limit of their natural distribution due to the climatic features of the Polesie lowland. In the complex, they form the space of the regional Polesie chorological disjunction, which is the dividing line between the plain (boreal) and mountain (Carpathian) parts of the ranges of some species: Picea abies (L.) Karst., Huperzia selago (L.) Bernh. ex Schrank et Mart., Bistorta major Gray [5].

A total of 16 species have a local disjunction in the Pripyat Polesie, which is caused by a combination of a number of natural (features of geomorphology and soil cover) and anthropogenic (consequences of drainage of swamps) factors. These include Betula humilis Schrank, Cephalanthera longifolia (L.) Fritsch, Filipendula vulgaris Moench, Hypericum montanum L., Plantago media L., Potentilla alba L., Salix myrtilloides L., Trolius europaeus L. and some other species that are absent from the valleys of the Yaselda and Styr rivers.

Currently, only 69 that grow on the borders of the areas have a Red book protection category (Iris aphylla L., Pulsatilla patens (L.) Mill.), 42 are on the list of preventive protection (Bistorta major Gray, Jurinea cyanoides Rchb.). Many horologically determined species (Alchemilla polessica Tretjakov, Chamaedaphne calyculata (L.) Moench), rare for Polesie and Belarus in General, remain outside the environmental legislation.

The category of probably extinct in the flora of Pripyat Polesie includes 29 species: Arnoseris minima (L.) Schweigg. et Körte, Caldesia parnassifolia (Bassi ex L.) Parl., Carex disperma Dewey, Coeloglossum viride (L.) Hartm., Corallorhiza trifida Châtel., Eriophorum latifolium Hoppe, Linnaea borealis L., Linosyris vulgaris Cass. ex Less., Linum flavum L., Listera cordata (L.) R. Br., Malaxis monophyllos (L.) Sw., Neottianthe cucullata (L.) Schltr., Pedicularis sylvatica L., Ranunculus illyricus L., Saxifraga hirculus L., Tofieldia calyculata Wahlenb., Trichophorum alpinum (L.) Pers. and others. Their participation in the modern flora of the region has not been confirmed for the past 40 years or more. Taking into account the possibility of their rediscovery in the future, these taxa also need to be taken into account when planning the implementation of environmental measures.

The presented data show that the flora of the Polesie lowland has a number of features that must be taken into account when selecting and protecting rare plant species. They are due to the geographical location of the region and the features of geomorphology, hydrography, climate and vegetation cover. Significant impact on the modern composition of the flora had the effects of anthropogenic influences (drainage of marshes, road construction, deforestation, plowing, etc.). The National Red Book of the Republic of Belarus does not allow to take into account the peculiarities of flora within the boundaries of individual natural regions of Belarus. In this regard, to effectively protect the diversity of the flora of the Belarusian Polesie, it is necessary to create regional "red lists" that take into account all aspects of the flora's sozology. 


\section{References}

1. The Red Book of the Republic of Belarus, plants. (Belorusskaya entsiklopediya, Minsk, 2015)

2. The National Atlas of Belarus (Belkartografiya, Minsk, 2002)

3. A. Mialik. Assessment of the current composition of the vascular plant flora of Pripyat Polesie, materials of the International Scientific Conference "Scientific Aspiration 2019”, 11-12 December, 2019, Minsk, Belarus (2019)

4. The Red Book of Ukraine, the plant world (Globalconsulting, Kiev, 2009)

5. V.I. Parfenov, Acta Bot. Fennica, 162. 129-132 (1999) 